\title{
Using SPADA Brightspace to Enhance Pedagogical Skills in Teacher Professional Program
}

\author{
https://doi.org/10.3991/ijet.v15i07.13371 \\ Bayu Kurniawan ${ }^{(凶)}$, Agus Purnomo, Idris, \\ Khofifatu Rohmah Adi, I Dewa Putu Eskasasnanda \\ Universitas Negeri Malang, Malang, Indonesia \\ bayu.kurniawan. fis@um.ac.id
}

\begin{abstract}
SPADA Brightspace is an e-learning platform designed for online Teacher Professional program learning activities. This platform has become a virtual learning environment with no boundaries of space and time between educators and students for a long time. It is equipped with various learning features and learning progress recorded by the system. This paper aims to determine the effectiveness of using SPADA Brightspace in improving pedagogical skills of participants in the Teacher Professional program. This research uses a quantitative approach using One Group Pretest-Posttest Design. Also, the effectiveness was measured by the result of pre and post-test given to the participants based on several indicators such as the ability to design course plan (RPP), to compile teaching materials, to produce learning media, to create student activity sheets (LKPD), and to make evaluation instruments. By using descriptive statistical analysis, this study found that the SPADA Brightspace platform was effectively used for improving pedagogical skills of participants.
\end{abstract}

Keywords-Online learning, SPADA Brightspace, Professional Teacher Program, pedagogical skills.

\section{Introduction}

In the Era of Industrial Revolution 4.0, education has increasingly developed in direct proportion to technological developments. It is said that online learning is a way that allows eliminating the boundaries of space and time [1]-[3]. It means that flexible education has been created [4], [5] in various parts of the world. This situation is due to the rapid development of information and communication technology. Blended learning gives new colors to the world of education. This also means that online learning does not necessarily shift the existence of face-to-face learning models such as project-based learning models [6], [7], problem-based learning [8], [9], cultural valuebased learning [10]-[12], and outdoor learning for experiential skills [3], [13]. All of this must be considered as progress that makes it easy to achieve the goals of education.

Various forms of online learning that often sound like web-based learning [14], [15] as well as application or platform-based learning such as e-learning [16], [17], Google Classroom [18], [19], game quiz [20], and MOOCs [21]-[23]. In addition, widelyknown application or platform-based learning is Edmodo [24]-[26]. 
In Indonesia, online learning also has excellent potential. One of them is to facilitate professional education as used in the Teacher Professional Program (PPG). Participants spread across various regions in Indonesia were met in virtual classes that had been designed in the Brightspace SPADA platform (see figure 1-3) and, furthermore, learning continued with face-to-face classes. This blended learning spearheaded the achievement of the goals of the Teacher Professional Program (PPG) in Indonesia to make teachers professional [27], [28]. Nevertheless, there are several things that need to be considered regarding the readiness of the participants who take part in this program. Considering the geographical participants of this program are teachers spread across various regions in Indonesia, of course, their quality and abilities will be different. Also, in terms of age, $81 \%$ of the participants of this program were birthed between 19641980 , which meant they were generation $\mathrm{X}$ who needed adaptation in joining the program [29], [30]. They are the new generation of information technology development and computer use. Thus, it is not surprising if among them, there are still difficulties in operating the computer independently.

\section{$2 \quad$ Method}

\subsection{Research subject}

Overall, this study involved all participants of the Teacher Professional Program (PPG) in Phase 2 of the Social Studies Course, which were 49 people (2 participants did not complete the online learning process). Based on the characteristics of the subject, there were $26.5 \%$ of the participants were male, while $73.5 \%$ were women. All participants are teachers who have taught in several years and have a Unique Educator and Education Personnel Number (NUPTK) determined by the government. Participants obtained five main independent learning programs that were repeated in 2 sessions including the preparation of lesson plans (lesson plans), teaching materials, learning media, student activity sheets (LKPD), and evaluation instruments. The entire indicator has been assessed by instructors who are qualified in the education sector, and the entire process is executed online.

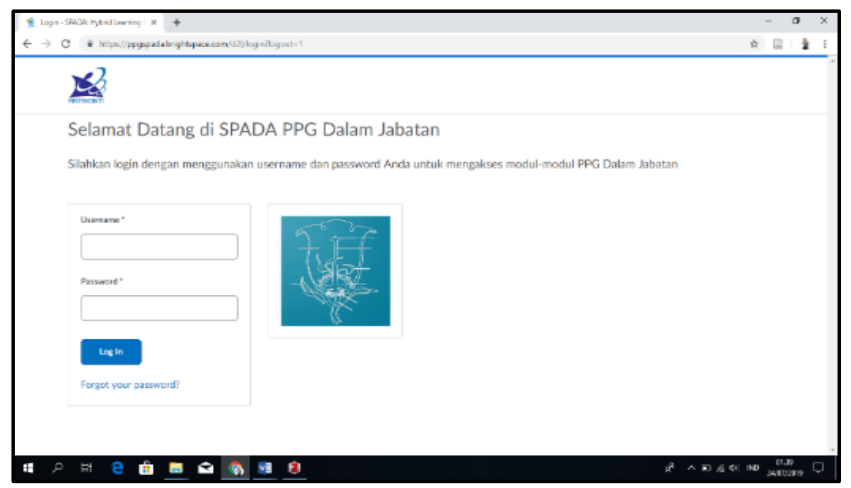

Fig. 1. Log in SPADA Brightspace 


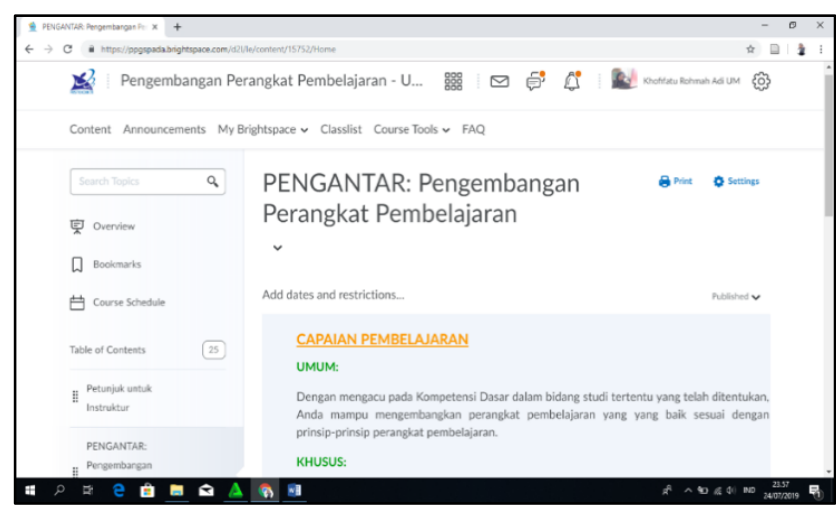

Fig. 2. Learning Module

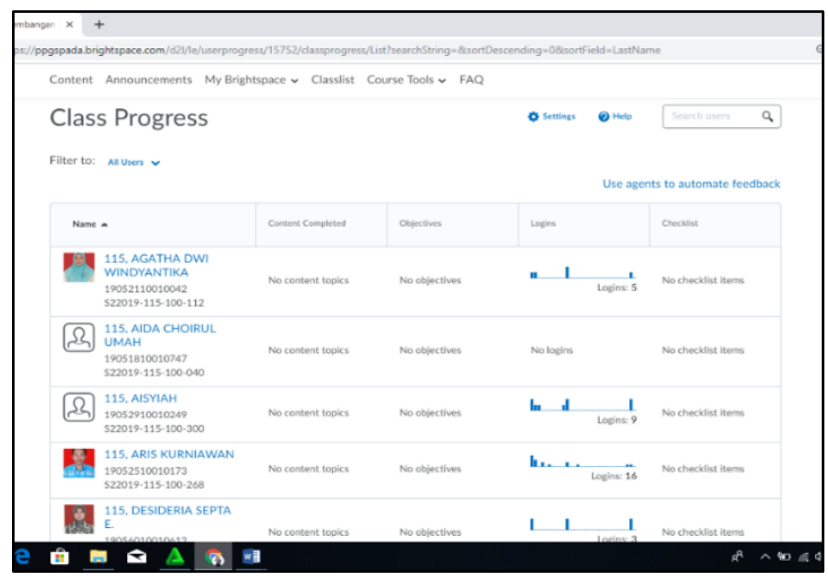

Fig. 3. Class Progress

\subsection{Data analysis}

To analyze data that had been collected through One Groups Pre and post-test design, descriptive statistical analysis was used. The results of the data were transferred and tabulated into the worksheet and analyzed using SPSS 16. Reliability was determined based on Cronbach Alpha. Also, to see the significant value between pre and post-test seen based on the results of the T-test. The result is as follow:

Table 1. Reliability Test

\begin{tabular}{|l|c|c|c|}
\hline \multicolumn{1}{|c|}{ Assesment Factor } & M & SD & Reliability \\
\hline Lesson Plan (RPP) & 76.21 & 16.82 & 0.960 \\
\hline Learning material & 75.88 & 17.66 & 0.915 \\
\hline Learning Media & 75.22 & 17.35 & 0.949 \\
\hline Student activities sheets (LKPD) & 79.439 & 20.53 & 0.846 \\
\hline Evaluation Instrument & 80.74 & 18.81 & 0.924 \\
\hline
\end{tabular}




\section{Result and Discussion}

Overall assessment of indicators generally indicates that there are changes in pedagogical skills obtained by online training participants after using SPADA Brightspace. The first assessment is the practice of designing a lesson plan (RPP). It was found that there was an increase in the ability of training participants with a significance value of $0.000<0.05$ with a strong correlation value of 0.934 (see table 2). The second assessment shows an increase in ability in the practice of preparing teaching materials of $0.000<0.05$ with a correlation value of 0.844 . Increasing the ability of participants to produce learning media is equal to $0.000<0.05$ with a correlation value before and after the treatment of 0.905 .

Furthermore, for the assessment of the preparation of student activity sheets (LKPD), the significance values obtained were $0.003<0.05$ with a correlation of 0.825 . Finally, the ability of participants in compiling learning evaluation instruments, the results of data analysis showed a significance value of $0.000<0.05$ and a correlation value of 0.948 . The details can be seen in table 2 .

Table 2. The Result of T-test

\begin{tabular}{|l|c|c|}
\hline \multicolumn{1}{|c|}{ Assesment Factor } & Correlation & Sig. (2-tailed) \\
\hline Lesson Plan (RPP) & 0.934 & 0.000 \\
\hline Learning material & 0.844 & 0.000 \\
\hline Learning Media & 0.905 & 0.000 \\
\hline Student activities sheets (LKPD) & 0.825 & 0.003 \\
\hline Evaluation Instrument & 0.948 & 0.000 \\
\hline
\end{tabular}

To understand in-depth about the findings of this study, it seems necessary to compare the results of previous studies and verify existing theories. Online learning has indeed been included in various education and training programs that were traditionally carried out. Training programs in the fields of health, business, education, language institutions, everything has been directed online, and various platforms have been used to simplify their programs.

The use of e-learning for training programs in companies has provided benefits in the form of cost-effective, convenient, and effective ways to deliver education for company employees (Ozturan \& Kutlu, 2010). This is a valuable bonus when the program is carried out as expected and with low costs. Also, online learning platforms such as Semantic Web-Based Learning (SWBL) have provided significant learning outcomes and learning satisfaction for participants in pre-service teacher training programs. The participants enjoyed the learning features available on the platform. In addition, ease of access and flexibility also much helps participants [31].

It seems that the support from the government is getting higher when online education programs can be a smooth way to take policies and continue them. An interesting thing was also found in the utilization of smartphone applications in childcare training programs. The use of smartphone applications in the program proved to support the retention of knowledge about child trauma for caregivers [32]. Today's parents may not need to worry; they have reliable and professional caregivers. In Bangladesh, there is a 
platform called Open Source Technology (OST) that has pedagogical capabilities. OST is said to be a suitable alternative for educational institutions in developing countries [33]. Some platforms also allow for online training assessment processes in language writing [34]. Now we can become chefs who have good and healthy nutrition knowledge just by attending online classes at MOOCs [35]. The evidence is not constructed only for business purposes, and our eyes are increasingly wide open to see it all. There is no need for anyone to be hostile to things that are traditional or contemporary.

The effectiveness of using the platform in online learning should be technically reviewed. At least several important factors support the success of online learning, including:

1) Technology

2) Instructors

3) Students [36].

Additional other supporting factors that are not less important are support from institutions [37]. In addition, technology is the top factor, which is usually the main factor. The ease of access to using platforms is essential. Learners and instructors, as users of online learning technologies, become a reference indicator for assessing accessibility. The most important, of course, is the aspect of student satisfaction in using the online learning technology [38]. The instructor, as the ruler of the virtual class, will certainly try his best in designing the material and instructions. In order for the virtual class to function properly, of course, the controller must function effectively and optimally. Stakeholders at the university also need to provide material support needed in the online learning process. Material aspects of support are certainly not cheap, but stakeholders should be aware of this.

\section{Conclusion}

The SPADA Brighspace facilitates participants to demonstrate effective learning outcomes. Overall, the results of the study prove that the use of SPADA Brighspace as an online learning platform is effective in improving training participants' pedagogical skills. These learning outcomes are based on the behavioristic learning process. In each session, training participants get feedback for improvement in the next session. Errors and shortcomings of work at each session provide insight to students about how the most appropriate way of doing assignments in the next session. This cycle is like the pattern of trial and error in behavioristic learning. Also, this research is supported by previous studies on various relevant platforms used for educational and training activities, both theoretical and practical. 


\section{$5 \quad$ References}

[1] R. A. Cole, Issues in Web-based Pedagogy: A Critical Primer. Greenwood Publishing Group, 2000.

[2] G. Cui and S. Wang, "Adopting cell phones in EFL teaching and learning," J. Educ. Technol. Dev. Exch. JETDE, vol. 1, no. 1, p. 6, 2008.

[3] B. Kurniawan, I. Idris, A. Purnomo, A. Wiradimadja, and S. Sukamto, "Using Broadcasting Learning Design to Enhance Student's Experiential Skill,” Int. J. Emerg. Technol. Learn. IJET, vol. 14, no. 16, pp. 172-180, Aug. 2019. https://doi.org/10.3991/ijet.v14i16. $\underline{10652}$

[4] T. Daymont, G. Blau, and D. Campbell, "Deciding between traditional and online formats: Exploring the role of learning advantages, flexibility, and compensatory adaptation," J. Behav. Appl. Manag., vol. 12, no. 2, pp. 156-175, 2011.

[5] F. Khalid, "Students' identities and its relationships with their engagement in an online learning community," Int. J. Emerg. Technol. Learn. IJET, vol. 14, no. 05, pp. 4-19, 2019. https://doi.org/10.3991/ijet.v14i05.8196

[6] S. Bell, "Project-based learning for the 21st century: Skills for the future," Clear. House, vol. 83, no. 2, pp. 39-43, 2010.

[7] L. Helle, P. Tynjälä, and E. Olkinuora, "Project-based learning in post-secondary educationtheory, practice and rubber sling shots," High. Educ., vol. 51, no. 2, pp. 287-314, 2006. https://doi.org/10.1007/s10734-004-6386-5

[8] D. Boud and G. Feletti, The challenge of problem-based learning. Psychology Press, 1998.

[9] C. E. Hmelo-Silver, "Problem-based learning: What and how do students learn?," Educ. Psychol. Rev., vol. 16, no. 3, pp. 235-266, 2004. https://doi.org/10.1023/b:edpr.00000340 $\underline{22.16470 .13}$

[10] B. Kurniawan, S. Sariyatun, and H. Joebagio, "Pengembangan Model Pembelajaran Ips Berbasis Nilai Simbolisme Kain Songket Untuk Meningkatkan Solidaritas Sosial Siswa Smp Negeri 6 Kayuagung," HISTORIKA, vol. 20, no. 1, 2016. https://doi.org/10.25273/ gulawentah.v1i1.28

[11] S. Sariyatun, "Pengembangan Model Pendidikan Nilai-Nilai Budaya di SMP Berbasis Tradisi Seni Batik Klasik Surakarta," Paramita Hist. Stud. J., vol. 23, no. 2, 2013.

[12] W. D. Sulistyo, "Pengembangan Model Pembelajaran Sejarah Berbasis Nilai-Nilai Serat Wicara Keras Untuk Meningkatkan Kemampuan Berfikir Kritis Siswa Sma Insan Cendekia Al Mujtaba Sukoharjo (PhD Thesis)," Univ. Sebel. Maret, 2016. https://doi.org/10. 32616/tdb.v7.1.36.61-70

[13] A. Purnomo, A. Wiradimadja, and B. Kurniawan, "Diversification of tourism product in KSPN Ijen," in IOP Conference Series: Earth and Environmental Science, 2019, vol. 243, p. 012079. https://doi.org/10.1088/1755-1315/243/1/012079

[14] J. L. Bele and J. Rugelj, "Comparing efficiency of web based learning contents on different media,” Int. J. Emerg. Technol. Learn. IJET, vol. 4, no. 2009, 2009. https://doi.org/10. 3991/ijet.v4s3.1087

[15] A. Jolliffe, J. Ritter, and D. Stevens, The online learning handbook: Developing and using web-based learning. Routledge, 2012.

[16] R. C. Clark and R. E. Mayer, E-learning and the science of instruction: Proven guidelines for consumers and designers of multimedia learning. John Wiley \& Sons, 2016. https://doi. org/10.1002/9781119239086

[17] D. R. Garrison, E-learning in the 21st century: A framework for research and practice. Routledge, 2011. 
[18] R. A. S. Al-Maroof and M. Al-Emran, "Students acceptance of Google classroom: An exploratory study using PLS-SEM approach,” Int. J. Emerg. Technol. Learn. IJET, vol. 13, no. 06, pp. 112-123, 2018. https://doi.org/10.3991/ijet.v13i06.8275

[19] S. Iftakhar, "Google classroom: what works and how," J. Educ. Soc. Sci., vol. 3, no. 1, pp. $12-18,2016$.

[20] K. R. Adi, Idris, and F. Rosyida, "Game Quiz Dalam Kegiatan Lesson Study Sebagai Penggugah Minat Belajar Mahasiswa,” Pros. Semin. Nas. Prodi Pendidik. IPS 2018, pp. 72 78, 2018.

[21] R. Boyatt, M. Joy, C. Rocks, and J. Sinclair, "What (Use) is a MOOC?," in The 2nd international workshop on learning technology for education in cloud, 2014, pp. 133-145. https://doi.org/10.1007/978-94-007-7308-0 15

[22] P. Kim, Massive open online courses: The MOOC revolution. routledge, 2014.

[23] W. D. Sulistyo, U. Nafi'ah, and I. Idris, "The Development of E-PAS Based on Massive Open Online Courses (MOOC) on Local History Materials,” Int. J. Emerg. Technol. Learn. IJET, vol. 14, no. 09, pp. 119-129, May 2019. https://doi.org/10.3991/ijet.v14i09.10143

[24] C. Hursen and F. G. Fasli, "The impact of reflective teaching applications supported by Edmodo on prospective teachers' self-directed learning skills,” Int. J. Emerg. Technol. Learn. IJET, vol. 12, no. 10, pp. 21-34, 2017. https://doi.org/10.3991/ijet.v12i10.6993

[25] A. Nasrullah, M. Marlina, and W. Dwiyanti, "Development of student worksheet-based college e-learning through Edmodo to maximize the results of learning and motivation in economic mathematics learning," Int. J. Emerg. Technol. Learn. IJET, vol. 13, no. 12, pp. 211229, 2018. https://doi.org/10.3991/ijet.v13i12.8636

[26] S. Wichadee, "A development of the blended learning model using Edmodo for maximizing students' oral proficiency and motivation," Int. J. Emerg. Technol. Learn. IJET, vol. 12, no. 02, pp. 137-154, 2017. https://doi.org/10.3991/ijet.v12i02.6324

[27] Kemendikbud RI, Peraturan Menteri Pendidikan Dan Kebudayaan Republik Indonesia Nomor 87 Tahun 2013 Tentang Program Pendidikan Profesi Guru Prajabatan. 2013. https:// doi.org/10.31219/osf.io/gepqc

[28] R. R. Pangestika and F. Alfarisa, "Pendidikan Profesi Guru (PPG): Strategi Pengembangan Profesionalitas Guru dan Peningkatan Mutu Pendidikan Indonesia," in Makalah Prosiding Seminar Nasional, 2015, vol. 9. https://doi.org/10.30998/prossnp.v1i0.31

[29] L. C. Lancaster and D. Stillman, When generations collide: Who they are, why they clash, how to solve the generational puzzle at work. HarperBusiness New York, NY, 2003. https://doi.org/10.5860/choice.40-6507

[30] D. Oblinger, J. L. Oblinger, and J. K. Lippincott, Educating the net generation. Boulder, Colo.: EDUCAUSE, c2005. 1 v.(various pagings): illustrations., 2005.

[31] H. Karalar and A. T. Korucu, "Effects of Semantic Web Based Learning on Pre-service Teachers' ICT Learning Achievement and Satisfaction,” J. Educ. Train. Stud., vol. 4, no. 8, pp. 150-160, 2016. https://doi.org/10.11114/jets.v4i8.1676

[32] A. D. Sullivan et al., "Feasibility investigation: Leveraging smartphone technology in a trauma and behavior management-informed training for foster caregivers," Child. Youth Serv. Rev., vol. 101, pp. 363-371, Jun. 2019, doi: https://doi.org/10.1016/j.childyouth. 2019.03.051.

[33] M. Hasan, S. H. Khan, and C. K. Clement, "Emerging Trends of Using Open Source Technology for Sustainable Teacher Training Programme in Bangladesh," Procedia - Soc. Behav. Sci., vol. 195, pp. 862-871, Jul. 2015, doi: https://doi.org/10.1016/j.sbspro.2015.06. $\underline{365}$. 
[34] C. Elder, G. Barkhuizen, U. Knoch, and J. von Randow, "Evaluating rater responses to an online training program for L2 writing assessment," Lang. Test., vol. 24, no. 1, pp. 37-64, Jan. 2007, doi: https://doi.org/10.1177/0265532207071511.

[35] M. Adam, K. C. Young-Wolff, E. Konar, and M. Winkleby, "Massive open online nutrition and cooking course for improved eating behaviors and meal composition," Int. J. Behav. Nutr. Phys. Act., vol. 12, no. 1, p. 143, Dec. 2015, doi: $\underline{\text { https://doi.org/10.1186/s12966 }}$ -015-0305-2.

[36] T. Volery and D. Lord, "Critical success factors in online education," Int. J. Educ. Manag., vol. 14, no. 5, pp. 216-223, Sep. 2000, doi: 10.1108/09513540010344731.

[37] H. M. Selim, "Critical success factors for e-learning acceptance: Confirmatory factor models," Comput. Educ., vol. 49, no. 2, pp. 396-413, Sep. 2007, doi: https://doi.org/10.1016/j. compedu.2005.09.004.

[38] J. Drennan, J. Kennedy, and A. Pisarski, "Factors Affecting Student Attitudes toward Flexible Online Learning in Management Education,” J. Educ. Res., vol. 98, no. 6, pp. 331-338, 2005. https://doi.org/10.3200/joer.98.6.331-338

\section{$6 \quad$ Authors}

Bayu Kurniawan is an Indonesian Historical Education, one of the lecturers in the Faculty of Social Science, Universitas Negeri Malang. His research interest is education and learning innovation.

Agus Purnomo is a lecturer in the Social Studies program, Faculty of Social Science Universitas Negeri Malang. His primary interest is in tourism and mobile learning research. He is the editor-in-Chief of the journals JTPPIPS at journal2.um.ac.id.

Idris is one of the lecturers in Social Studies Program, Faculty of Social Science, Universitas Negeri Malang. He is interested in learning innovation.

Khofifatu Rohmah Adi is an Economic Education, one of the lecturers in the Faculty of Social Science, Universitas Negeri Malang. Her research interest is education and green economy.

I Dewa Putu Eskasasnanda is a lecturer in the Social Studies program, Faculty of Social Science Universitas Negeri Malang. He is majoring in lesson study.

Article submitted 2020-01-23. Resubmitted 2020-02-06. Final acceptance 2020-02-06. Final version published as submitted by the authors. 